РОСТ СКОРОСТИ ПЕРЕВОЗОК ПАССАЖИРОВ

НА БАЗЕ ИСПОЛЬЗОВАНИЯ ЛОГИСТИЧЕСКИХ МУЛЬТИМОДАЛЬНЫХ ТЕХНОЛОГИЙ

\author{
Е. М. Волкова
}

Петербургский государственный университет путей сообщения Императора Александра I (Санкт-Петербург, Россия)

\title{
INCREASING OF PASSENGER TRANSPORTATION SPEED WITH LOGISTIC MULTIMODAL TECHNOLOGIES APPLYING
}

\author{
E. M. Volkova \\ Emperor Alexander I \\ Petersburg State Transport University \\ (St. Petersburg, Russia)
}

На сегодняшний день большую актуальность приобретают вопросы роста скорости пассажирских перевозок как в дальнем следовании, так и в пригородном сообщении, а также в городских транспортных системах. Это связано с укрупнением агломераций, повышением мобильности населения, необходимостью рационального использования рабочего и свободного времени. На наш взгляд, резервы роста скорости пассажирских перевозок кроются не только в развитии новых видов скоростного транспорта (высокоскоростные магистрали, магнитолевитационный транспорт), но и в сокращении времени в пути благодаря высокому уровню координации видов транспорта.

Прежде всего взаимодействие видов транспорта может быть реализовано путём организации мультимодальных перевозок. Нормативно-правовая база не закрепляет определение данной категории, однако большинство исследователей сходятся 
во мнении, что мультимодальная пассажирская перевозка предполагает участие нескольких видов транспорта при их тесном взаимодействии и централизованном управлении процессом перевозки.

Анализ мировой практики развития мультимодальных перевозок и российского опыта показал, что наиболее распространенными схемами в дальнем следовании является взаимодействие железнодорожного транспорта и автотранспорта, железнодорожного и воздушного транспорта (при перевозках «город - аэропорт»), существуют примеры железнодорожно - паромного сообщения. В региональных и городских транспортных системах в основу положены высокопроизводительные виды транспорта (метрополитен, городская железная дорога), к ним подключаются другие виды общественного транспорта (автобусы, троллейбусы, маршрутные такси), а также личный автотранспорт.

Для развития мультимодальных перевозок необходима не только организация самого процесса, но и развитие соответствующей инфраструктуры, а также информационных технологий. Так, появление перехватывающих парковок вблизи конечных станций метрополитена способствует перераспределению пассажиропотоков в пользу общественного транспорта. Во всём мире развиваются транспортнопересадочные узлы (ТПУ), обеспечивающие быструю и комфортную смену видов транспорта для пассажира. Появляются новые виды интернет-сервисов и мобильных приложений, позволяющих пассажиру планировать поездку с наименьшими временными затратами. Наконец, немаловажное значение имеет интеграция каналов продаж транспортных организаций. Появление единого билета на все виды общественного транспорта в городах значительно экономит не только деньги пассажира, но и его время. Оно выгодно и участникам рынка, поскольку способствует сокращению трудозатрат на обслуживание пассажиров в кассах. Таким образом, наряду с развитием новых видов транспорта резервы роста скорости пассажиров кроются и в повышении эффективности взаимодействия, развитии мультимодальных перевозок традиционными видами пассажирского транспорта. 


\section{Сведения об автору:}

Волкова Елена Михайловна, moonlight34@yandex.ru

Information about author:

Elena M. Volkova, moonlight34@yandex.ru 